\title{
Irrelevant, Overlooked, or Lost? Trends in 20 Years of Uncited and Low-cited K-12 Online Learning Articles
}

\author{
Karen Arnesen \\ Brigham Young University \\ Shea Walters and Jered Borup \\ George Mason University \\ Michael K. Barbour \\ Touro University California
}

\begin{abstract}
In this study, we analyzed a subset of uncited or low-cited articles from the data reported in Arnesen, Hveem, Short, West, and Barbour (2019), who examined the trends in K-12 online learning articles from 1994 to 2016. We identified 62 articles that had 5 or fewer citations, and analyzed them for trends in authorship, publication outlets, dates of publication, and topics that could help explain their low citation numbers. We also analyzed topics to see what contribution they might have made and can still make to the field of K-12 online learning. We found that the majority of these articles had been published in many different, less well-known journals. We also found that these articles may have attracted fewer readers because they addressed topics that seemed to have a narrow focus, often outside of the U.S. The articles were also authored by both well-known researchers in the field, as well as a number of one-time authors. What we did not find were articles that were uninteresting, poorly researched, or irrelevant. Many of the articles described and discussed programs that grappled with and overcame some of the same challenges online learning still faces today: issues of interaction, community, technology, management, etc. Some of the early articles gave interesting insights into the history of K-12 online learning, especially as it involved rural learners and programs. Others addressed less mainstream but still interesting topics such as librarians in online learning, cross-border AP history classes, policies that helped or hindered the growth of online learning, and practical considerations of cost and access.
\end{abstract}

Keywords: distance education, telelearning, e-learning, K-12 online learning, virtual school, cyber school, citation analysis, journal analysis

Arnesen, K., Walters, S., Barbour, M.K., \& Borup, J. (2020). Irrelevant, overlooked, or lost? Trends in 20 years of uncited and low-cited K-12 online learning articles. Online Learning, 24(2), 187-206. https://doi.org/10.24059/olj.v24i2.2080 


\section{Irrelevant, Overlooked, or Lost? Trends in 20 Years of Uncited and Low-cited K-12 Online Learning Articles}

Systematic reviews of a particular field are useful at periodic intervals. For example, Zawacki-Richter, Baecker, and Vogt (2009) examined the various research areas, research methods, and authorship patterns of the broad field of distance education from 2000 to 2008 based on their analysis of five journals in the field. Bozkurt et al. (2015) similarly conducted a similar analysis of the trends in research topics in the field of distance education based on their review of research articles in seven distance education journals from 2009 to 2013. Within the K-12 environment, Arnesen, Hveem, Short, West, and Barbour (2019) were the first to provide that systematic review of the field of K-12 online learning. Arnesen and her colleagues reviewed 356 articles from 155 journals, representing what they believed was "the majority of published K-12 online learning scholarship" (p. 36), to determine trends in the authors, journals, citations, topics, and research methodology.

As a part of their analysis, Arnesen et al. reported that each of the top 20 cited articles had been cited at least 107 times. That figure rose to at least 241 citations for the top 10 cited articles and at least 350 citations for the top five cited articles. However, the authors did not make any reference to the articles on the opposite end of that spectrum (i.e., those that had not been cited or that had only received a small number of citations). As the authors made their data set available for further analysis (https://tinyurl.com/K12OnlineLearningData), the raw data appeared to indicate that there were 23 possible articles that had not been cited at all and 91 possible articles that had received five or fewer citations. These figures represented almost a third (i.e., 32\%) of the overall data set. The large number of uncited or low-cited articles was surprising considering K12 online learning researchers frequently lament that research in the field is lacking. We believed that while these articles appeared to be overlooked by the field a closer examination of them had the potential to further the fields' efforts. In a discussion of uncited research, Van Noorden (2017) noted, "some researchers might still be tempted to dismiss uncited papers as irrelevant. After all, if they mattered — even a little bit—wouldn't someone have mentioned them?" (p. 164).

This particular question intrigued us in relation to these articles. Arnesen et al. (2019) did not comment on the uncited or low-cited articles in their data set. In doing so they, highlighted patterns in the research that was already recognized in the field, but failed to shed light on those articles previously overlooked by the field. As such, we are unable to determine if there were any patterns to this research when it came to authorship, the journals that the articles were published in, the specific topics researched, or methodologies used. Were there possible patterns in any of these areas? What might be learned from this largely unmentioned body of K-12 online learning research? To address these types of questions, we engaged a study of our own to examine what trends existed in the journal articles identified by Arnesen and her colleagues that had five or fewer citations.

\section{Review of Relevant Literature}

We began our exploration of these uncited and low-cited articles by trying to understand exactly how common the phenomenon actually was. For example, in an article in Science magazine, Hamilton (1990) suggested that 55\% of the articles published in journals indexed by the Institute for Scientific Information (ISI) from 1981 and 1985 were uncited in the five years after their publication. He went on to suggest that — when broken down by discipline $-47.4 \%$ of 
articles in the sciences went uncited, $74.7 \%$ of articles in the social sciences went uncited, and $98.0 \%$ of articles in the arts and humanities went uncited. However, only three months later, Science published numerous letters in response to that article that contested those figures and also suggested that restricting the analysis to five years after publication artificially inflated the number of uncited articles (Tainer et al., 1991). More recently, Van Noorden's (2017) analysis of more than 39 million articles representing over 12,000 journals in the Web of Science from 1990 to 2015 found that approximately $21 \%$ were uncited. Van Noorden did acknowledge that the true number of uncited articles was or would be much lower, as many journals and other publication outlets were not indexed by the Web of Science. Similarly, if the author made a typographical error in their manuscript when citing an article, the automated features of the indexing service might not attach the citation to the correct reference. Finally, as his article was published in 2017, it was likely that many of the articles from 2015 and other more recent years would eventually be cited once they had achieved sufficient longevity in the body of knowledge in their respective field. Simply put, there were likely fewer uncited articles than we believe and could be any number of reasons why that was the case.

The issue of publications not being indexed by various services is a particularly relevant one for the field of K-12 online learning. For example, Barbour and Reeves (2009) indicated that "much of the literature for virtual schooling has primarily been disseminated through private research centers, evaluations or doctoral dissertations" (p. 403). More recently, Lowes and Lin (2018) described the field as regularly publishing chapters in edited collections, book-length academic studies, program evaluations, guidelines and standards, popular media articles, and reports written by research organizations - often designed for policy or advocacy purposes; along with journal articles. Clark (2018) underscored the importance of program evaluation and the significant impact that it has had on the early scholarship in K-12 online learning. Essentially, scholars have regularly reported that significant portions of K-12 online learning research has been published in outlets not indexed by most services.

Who is publishing research on $\mathrm{K}-12$ online learning is as important, and complicated, as where that research has been published. Earlier Barbour (2007), who wrote about various individuals who were publishing or presenting in the field of K-12 distance and online learning, described seven recent graduates who "completed thesis or dissertations over the last five or six years that have been based upon a variety of aspects dealing with virtual schooling" (p. 9), out of a total of 15 researchers referenced in the article. Seven years later Lowes (2014) wrote that "as the body of research grows, the field attracts more researchers; and as these researchers take faculty positions, research on online teaching and learning becomes an increasingly acceptable academic pursuit for their graduate students" (p. 100). However, as Arnesen et al. (2019) reported, 276 of the 384 authors who had published an article related to K-12 online learning had published only a single article, which might suggest many of these authors were graduate students that were publishing the results of their Master's thesis or doctoral dissertation (and never published in the field again). Barbour lamented that the "additional fragmentation of where and how scholarship [was] published further complicates researchers' ability to situate their own studies within the historical origin and conceptual growth of the field" (Molnar et al., 2019, p. 62).

In fact, there have only been a few systematic examinations of the scholarship related to K-12 distance and online learning. One examination was conducted by Barbour (2011), who reviewed 262 articles from 2005 to 2009 published in a major distance education journal published in Australia, Canada, New Zealand, and the United States. Barbour found only 24 articles (or less 
than $10 \%$ ) related to K-12 distance and online learning, with 18 of those 24 articles having a North America focus. More recently, Barbour (2018) analyzed the Journal of Online Learning Research from 2015 to 2017 and found that the vast majority of articles that had been published focused on the U.S. As a follow-up to those results, Hu, Arnesen, Barbour, and Leary (2019) analyzed all 51 articles published between 2015 and 2018 (inclusive) in the Journal of Online Learning Research and found that 42 had a geographic focus on the U.S. There was only one article each focused on Turkey, Brazil, and India, as well as one focused on multiple countries. Finally, there were five articles that had no specific geographic focus. Barbour (2018) summarized the situation when he wrote that "the vast majority of the scholarship that [was] published focused on the United States (and to a lesser extent North America), even though there [was] a great deal of K-12 online... learning occurring outside of the United States" (p. 23).

Beyond these general observations, the Arnesen et al. (2019) study represents the most systematic review of research in the field of K-12 distance and online learning. This examination found that the field had grown significantly in recent years - both in terms of the number of articles and the introduction of new authors. The authors also reported that the field had initially focused on theoretical articles but was maturing and included more data-driven articles. Finally, Arnesen and her colleagues found the research was scattered among many journals. As the most detailed examination of journal articles in the field of K-12 distance and online learning, this review is not only worthy of further investigation, but the open data set begs further analysis.

\section{Methods}

The purpose of the Arnesen et al. (2019) study was to "analyze K-12 online learning research based on the journal articles that [had] been published in the field from 1994 to 2016" (p. 33). The purpose of this study was to examine what trends existed in the journal articles identified by Arnesen and her colleagues that had five or fewer citations. Using the articles published prior to the end of 2015 in the data set provided by Arnesen et al. ${ }^{1}$ (see pages 35-36 of that article to review the methods utilized to select those articles), we confirmed all of the articles that had five or fewer citations as of 31 August 2018 and updated the list appropriately. We excluded articles from 2016 as we felt these were two recent to have significant citations and would skew our overall data set. These data were then divided into two data sets: uncited articles (i.e., articles with no citations) and low-cited articles (i.e., articles with five or fewer citations).

\section{Journal Analysis Procedures}

We analyzed the collected articles for trends in citations, authorship, publishing year, and publishing journal using procedures consistent with the procedures used by Arnesen et al. (2019) for the complete data set (who followed the procedures outlined in "Journal Analysis Series" [West 2011, 2016]).

Authorship. In order to determine any trends of authors with uncited or low-cited articles, we first pulled a list of articles from the Arnesen et al. (2019) data set that appeared to have no citations or were identified as having low citations according to Google Scholar. Once the articles were identified we separated them into uncited and low-cited lists. From these lists we analyzed the authors for each article to identify those who had authored multiple articles in the sample.

\footnotetext{
${ }^{1}$ The full data set was provided by those authors at https://tinyurl.com/K12OnlineLearningData.
} 
Specifically, we assigned points to each author based on their position of authorship: three points for first authorship, two points for second author, and one point for third author or beyond. When the point totals were finalized, we then organized the authors based on their rank.

Publishing year. All of the articles were in two spreadsheets, one for uncited and one for low-cited. In order to determine how many were published each year, we filtered the spreadsheets by publishing year. We then determined how many articles were published for each year separately before combining them to determine the total number of uncited and low-cited articles per year.

Journal publishings. Similar to publishing year, we sorted the spreadsheets by journal to determine how many journals were represented and how many articles were published from each journal. After determining how many uncited and low-cited articles were within each journal, we went back to the complete Arnesen et al. data set to determine the number of journals in the complete set. Finally, we then established the overall journal ranking, analyzing the journals for any trends within cited and uncited articles and their corresponding journals.

\section{Analysis of Uncited and Low-cited Articles}

Two researchers read each of the uncited and low articles, and took notes separately regarding the articles' focus, research questions, context, findings, and stated implications. Each researcher then independently listed possible reasons why the article had not been cited as well as possible contributions the article could make to the current K-12 online and blended learning research. Each researcher then individually examined their notes across all articles to identify trends which they then listed. Lastly, one researcher reviewed both sets of notes and wrote a summary of the trends which the other researcher reviewed for accuracy.

\section{Results and Discussion}

In the following sections we describe and discuss the results of the journal analysis procedures, the analysis of the population of uncited articles, and the analysis of the population of low-cited articles.

\section{Journal Analysis Procedures}

Prior to drawing overall conclusions, we will discuss the findings for the different types of analyses conducted for this study. This study included 62 total articles written by 97 distinct authors. The average number of authors per article was $1.85(S D=0.95)$ with 26 of the articles being single-authored. Table 1 shows the ranking of the authors according to their authorship of uncited and low-cited articles. It is important to remember that the articles in the uncited population were not included in the population of low-cited articles. As such, it is interesting to see that three of the authors appeared on both lists (i.e., Barbour, Greer, and Stevens). Further, along with these three individuals, Beck, Cavanaugh, Davis, Murphy, Oliver, Russell, and Smith (or 10 of the 22 names listed), all appeared on the list compiled by Arnesen et al. (2019) of authors who published the most articles. This consistency would seem to indicate that the authors who were uncited or low-cited were still well known authors and their work should have been known in the field. Murphy, who for this study was one of the low-cited authors, was among the most cited authors from the 2001-2010 analysis of the British Journal of Educational Technology (Halverson et al., 2014). Cavanaugh was referenced as a most cited author between the years of 2002-2011 for International Review of Research in Online and Distance Learning (Olsen et al., 2013). Both of 
these examples further support that authors who are on this list of uncited or low-cited articles can still be well known.

Table 1

Top Authors by Number of Publications for Uncited and Low-cited Articles

\begin{tabular}{ccccccc}
$\begin{array}{c}\text { \# of } \\
\text { Uncited } \\
\text { Articles }\end{array}$ & $\begin{array}{c}\text { Uncited } \\
\text { Author }\end{array}$ & $\begin{array}{c}\text { Uncited } \\
\text { Points }\end{array}$ & $\begin{array}{c}\text { Rank } \\
2\end{array}$ & $\begin{array}{c}\text { \#f Low- } \\
\text { cited } \\
\text { articles }\end{array}$ & $\begin{array}{c}\text { Low-Cited } \\
\text { Author }\end{array}$ & $\begin{array}{c}\text { Low- } \\
\text { Cited } \\
\text { Points }\end{array}$ \\
1 & Barbour, M. K. & 6 & $\mathbf{1}$ & 5 & Barbour, M. K. & 15 \\
1 & Carr-Chellman, A. A. & 3 & $\mathbf{2}$ & 5 & Stevens, K & 15 \\
1 & Cavanaugh, C. & 3 & $\mathbf{3}$ & 3 & Beck, D. & 7 \\
1 & Davis, N. E. & 3 & $\mathbf{4}$ & 2 & Coy, K. & 6 \\
1 & Greer, D. L. & 3 & $\mathbf{5}$ & 2 & Garrett Dikkers, A. & 6 \\
1 & Haughey, M. & 3 & $\mathbf{6}$ & 2 & Russell, G. & 6 \\
1 & Mayse, D. & 3 & $\mathbf{7}$ & 2 & Greer, D. L. & 5 \\
1 & McWatters, G. & 3 & $\mathbf{8}$ & 2 & Murphy, E. & 5 \\
1 & Stevens, K. & 3 & $\mathbf{9}$ & 2 & Hirschmann, K. R. & 4 \\
1 & Dibbon, D. & 2 & $\mathbf{1 0}$ & 2 & Oliver, K. M. & 4 \\
1 & Kinsella, J. & 2 & $\mathbf{1 1}$ & 1 & 31 authors & 3 \\
1 & Muirhead, B. & 2 & $\mathbf{1 2}$ & 1 & 27 authors & 2 \\
1 & Smith, S. J. & 2 & $\mathbf{1 3}$ & 1 & 14 authors & 1 \\
1 & Thompson, L. A. & 2 & $\mathbf{1 4}$ & & & \\
\hline
\end{tabular}

Further Table 2 provides the ranking of authorship by combining the data for the low- and non-cited articles together. From the total list of 62 articles, 33 (i.e., 53\%) of them were written by the top 11 authors. The number of articles written by the top authors were either five, three, or two. The top two authors, Barbour and Stevens, are both first authors on each of their articles represented in this data. Of the seven articles Barbour authored, he wrote four independently, and brought in coauthors on three more. Stevens was the sole author on five of his articles and a coauthor on the sixth. This could potentially suggest the authors' high interest in the field; however, this data does not include all of their articles and therefore a further analysis of these authors may reveal different interests. 
Table 2

Top Authors by Number of Publications When Combining Uncited and Low-cited articles

\begin{tabular}{clc} 
\# of Articles & \multicolumn{1}{c}{ Author } & Points \\
7 & Barbour, M. K. & 21 \\
6 & Stevens, K & 18 \\
3 & Beck, D. & 7 \\
2 & Coy, K. & 6 \\
2 & Garrett Dikkers, A. & 6 \\
2 & Russell, G. & 6 \\
3 & Greer, D. L. & 8 \\
2 & Murphy, E. & 5 \\
2 & Hirschmann, K. R. & 4 \\
2 & Oliver, K. M. & 4 \\
2 & Smith, S. J. & 5 \\
1 & 38 authors (first author) & 3 \\
1 & 31 authors (second author) & 2 \\
1 & 15 authors (third or later author) & 1 \\
\hline
\end{tabular}

Table 3 looks at the number of articles written per year for uncited and low-cited articles.

Table 3

Number of Articles per Year for Uncited Low-cited Articles

\begin{tabular}{cccc} 
Year & Uncited Articles & Low-cited Articles & Total \\
1995 & 0 & 1 & 1 \\
1996 & 0 & 0 & 0 \\
1997 & 1 & 1 & 2 \\
1998 & 0 & 2 & 2 \\
1999 & 1 & 0 & 1 \\
2000 & 0 & 1 & 1 \\
2001 & 0 & 2 & 2 \\
2002 & 2 & 0 & 2 \\
2003 & 1 & 1 & 2 \\
2004 & 0 & 1 & 1 \\
2005 & 0 & 2 & 2 \\
2006 & 0 & 1 & 1 \\
2007 & 0 & 2 & 2 \\
2008 & 1 & 1 & 2 \\
2009 & 0 & 2 & 2 \\
2010 & 0 & 1 & 1 \\
2011 & 0 & 3 & 3 \\
2012 & 1 & 2 & 3 \\
2013 & 0 & 5 & 5 \\
2014 & 1 & 10 & 11 \\
2015 & 2 & 14 & 16 \\
Total & $\mathbf{1 0}$ & $\mathbf{5 2}$ & $\mathbf{6 2}$ \\
\hline
\end{tabular}


Of the 62 articles, 27 of them (i.e., $43.5 \%$ ) were written in the final two years represented in our data (i.e., 2014 and 2015). Furthermore, the year 2013 was the first instance of more than three articles. This growth suggests a number of possibilities. The most probable possibility is that articles published so recently have not had much time to accrue citations. Another possibility is that there was an increase of focus within the field starting in 2013, with the majority of the increase taking place in 2014 at approximately $17 \%$ and 2015 at approximately $26 \%$. Barbour (2011) referenced a large growth in the number of students enrolled in online schooling from the year 2000-2009, which would support an increase of focus in the field. However, while interest in the subject area may have expanded during the later years, because these articles are uncited and low-cited, this may indicate that the focus of these articles have not aligned with the focus of many other researchers. Furthermore, Barbour (2007) identified several of the authors (Cavanaugh, Murphy, Stevens, and Muirhead) in this data set as individuals who were already researching in this field, in particular virtual schools, prior to the year 2007. Therefore, an analysis consisting of a greater data set would be needed to further support this inference of growth in the later years.

Previously, we looked at the top authors in both the cited and uncited articles. Of the top 11 authors, only two were authors within the journals that published the most K-12 online learning research. Owens authored one article from the Journal of Online Learning Research and Beck authored an article in the Journal of Open, Flexible and Distance Learning. This data suggests that even though they are authoring the highest number of articles, the top 10 authors in this sample are not always publishing in the top publishing journals. It is important to note, that while this is the case for this data set, the authors may have more articles that are not covered in this analysis.

Table 4 shows the number of uncited and low-cited articles published by each journal in the data set. Arnesen et al.'s (2019) study included a corpus of journal articles focused on K-12 online and distance learning totaling over 350 articles. This table includes the data from that study, and shows the number of articles written in the original or complete data set gathered for this study and its overall ranking as a top publishing journal in the field of K-12 online learning (Arnesen et al., 2019).

As might be expected, the majority of the articles, 32 articles (i.e., 52\%) of the 62 lowcited or uncited articles, fell into the lowest ranking of journals (i.e., twenty-ninth and forty-ninth) from the original data set in Arnesen et al. (2019). Because of the low ranking of these journals, it is likely that their exposure to the field of K-12 online learning is low, thus indicating that the articles published within them would be less likely to be cited in other research. Conversely, the top overall ranked journal (i.e., Journal of Online Learning Research) in the original data set represented $16 \%$ of the uncited and low-cited articles that were published. This might suggest that being published in Arnesen et al.'s top journals does not guarantee an article will be cited in other's research. However, all of the uncited and low-cited articles in the Journal of Online Learning Research were published in the last year of this study, so the high percentage might also represent insufficient time for these articles to accrue a significant number of citations. 
Table 4

Top Publishing Journals of Uncited and Low-Cited K-12 Online Learning Articles

\begin{tabular}{|c|c|c|c|c|c|}
\hline & $\begin{array}{c}\text { \# of } \\
\text { uncited } \\
\text { articles }\end{array}$ & $\begin{array}{l}\text { \# of low- } \\
\text { cited } \\
\text { articles }\end{array}$ & $\begin{array}{c}\text { Total \# of } \\
\text { uncited } \\
\text { and low- } \\
\text { cited } \\
\text { articles }\end{array}$ & $\begin{array}{l}\text { Overall \# of } \\
\text { articles in } \\
\text { Arnesen et } \\
\text { al.'s (2019) } \\
\text { complete } \\
\text { data set }\end{array}$ & $\begin{array}{l}\text { Overall actual } \\
\text { ranking of } \\
\text { journals by } \\
\text { Arnesen et al.'s } \\
\text { (2019) complete } \\
\text { data set }\end{array}$ \\
\hline $\begin{array}{l}\text { Journal of Online Learning } \\
\text { Research }\end{array}$ & 1 & 9 & 10 & 25 & 1 \\
\hline $\begin{array}{l}\text { International Journal of E- } \\
\text { Learning \& Distance } \\
\text { Education }^{2}\end{array}$ & 1 & 1 & 2 & 14 & 3 \\
\hline $\begin{array}{l}\text { Journal of Open Flexible and } \\
\text { Distance Learning }\end{array}$ & 0 & 3 & 3 & 13 & 4 \\
\hline TechTrends & 0 & 1 & 1 & 12 & T5 \\
\hline The Morning Watch & 0 & 3 & 3 & 9 & 7 \\
\hline Distance Learning & 0 & 3 & 3 & 8 & $\mathrm{~T} 8$ \\
\hline $\begin{array}{l}\text { Journal of Research on } \\
\text { Technology in Education }\end{array}$ & 0 & 1 & 1 & 7 & $\mathrm{~T} 11$ \\
\hline Teaching Exceptional Children & 0 & 1 & 1 & 7 & $\mathrm{~T} 11$ \\
\hline $\begin{array}{l}\text { British Journal of Educational } \\
\text { Technology }\end{array}$ & 0 & 1 & 1 & 6 & $\mathrm{~T} 14$ \\
\hline $\begin{array}{l}\text { Computers in New Zealand } \\
\text { Schools }\end{array}$ & 1 & 0 & 1 & 6 & T14 \\
\hline $\begin{array}{l}\text { Turkish Online Journal of } \\
\text { Distance Education }\end{array}$ & 0 & 2 & 2 & 5 & T19 \\
\hline Educational Considerations & 0 & 1 & 1 & 4 & 20 \\
\hline $\begin{array}{l}\text { International Electronic Journal } \\
\text { for Leadership in Learning }\end{array}$ & 1 & 0 & 1 & 3 & $\mathrm{~T} 21$ \\
\hline Six journals & 0 & 6 & 7 & 2 & $\mathrm{~T} 29$ \\
\hline Twenty-six journals & 6 & 20 & 26 & 1 & T49 \\
\hline
\end{tabular}

${ }^{2}$ Formerly the Journal of Distance Education

${ }^{3}$ Formerly the Journal of Distance Learning 


\section{Analysis of Uncited Articles}

When examining the list of uncited articles and working to obtain the actual articles, it became clear that some were published in more obscure outlets. For instance, we were unable to access articles published in the Journal of the Illinois Council for the Social Studies (Barbour \& Kinsella, 2003) and Computers in New Zealand Schools (Davis, 2012) through our universities' robust library subscriptions and had to obtain them through interlibrary loans. Ease of access can impact how widely research is read and thus cited. Research has found that open access journals tend to have higher CiteScores ( $\mathrm{Li}, \mathrm{Wu}, \mathrm{Yan}, \& \mathrm{Li}, 2018)$ and that open access articles receive an average of $18 \%$ more citations than paywalled articles (Piwowar et al., 2018). However, ease of access does not ensure that an article is cited and some of the publication outlets on our list of uncited articles were open access such as the Journal of Online Learning Research (Mayse, 2015), the E-Learn Magazine (Carr-Chellman, 2015), and the Journal of Distance Education (McWatters \& Thompson, 1997). As a result, access is likely an important factor for some articles but was perhaps not the most important reason that some articles went uncited. It is also important to note that publishing in more obscure journals may reduce the likelihood that the article is cited by other researchers, but it can help researchers to reach smaller but important audiences.

In reading the articles, the first trend that we noticed was that of the 10 uncited articles, six were focused on K-12 online and blended learning contexts outside of the U.S. Of those six articles, five focused on Canada (Barbour, 2002; Barbour \& Kinsella, 2003; Haughey \& Muirhead, 1999; McWalters \& Thompson, 1997; Stevens \& Dibbon, 2002) and the other focused on New Zealand (Davis, 2012). As a field we tend to focus on online and blended learning in the U.S., which may help to explain why research articles focused on the U.S. were underrepresented in our list of uncited articles. Barbour (2018) stated:

Many of us who have been involved in K-12 online and blended learning, both practitioners and researchers, are familiar with the development of the field within the United States. Unfortunately, many who are involved in the field cannot say they have the same level of familiarity of the history, development, and/or current status of K-12 online and blended learning outside of the United States. (p. 21)

As a field, we should begin to expand our focus beyond the borders of the U.S. As we do, the six international articles on this list may provide helpful context. This is especially true because many of the articles actually described the history and development of online and blended learning in Canada and New Zealand. Four of the uncited articles specifically discussed online learning in rural settings and would be of particular interest to those who are interested in online learning in those types of settings. Furthermore, Davis's (2012) uncited article provides a helpful snapshot of issues and events related to K-12 online learning in New Zealand and stated that online and blended learning "is essential for New Zealand's rural populations and also of benefit to many more, including underserved Maori and Pacifika students" (p. 70). As a result, those wishing to learn more about how online and blended learning can address the needs of underserved students can look to New Zealand for examples.

Of the 10 uncited articles, six did not formally collect and analyze original data. Valuable research does not require original data collection and analysis. For instance, an analysis of articles published between 2001-2010 in 10 major journals in the field of instructional design and technology found that seven of the nine top-cited articles were labeled as theoretical or "non-data based papers" (West \& Borup, 2014, p. 548). However, unlike the articles in our list of uncited 
articles, the most cited non-data-based articles that West and Borup identified presented theoretical or design frameworks or rigorous literature reviews. In contrast, the uncited, non-data-based articles that we identified tended to focus on describing specific programs or practices, not on making broad theoretical contributions. The articles also varied in how much they referenced and cited previous research themselves. For instance, Carr-Chellman's (2015) article was peerreviewed, but was a short (i.e., about 1,300 words) commentary based on only a few articles and blog postings, as well as her personal experiences with cyber school advertising. Regardless, CarrChellman's commentary provided an interesting and helpful critique of cyber- school funding, as well as how that funding was (mis)spent. While these types of commentaries may not have been cited in research articles, Carr-Chellman's commentary could still make an important contribution to conversations that may lead to rigorous research. Similarly, much of Davis's (2012) uncited article actually highlighted keynotes and other presentations at the Distance Education Association of New Zealand 2012 conference. It is possible that Davis' article has helped researchers to identify helpful research, even though it has not been cited itself.

The other uncited, non-data-based articles described valuable online teaching strategies that researchers should be aware of. For instance, research examining learner-learner collaboration and communication is especially lacking. A national survey of online charter schools in the U.S. found that only $32 \%$ of online high schools frequently engaged students in teacher-guided synchronous discussions and only $21 \%$ frequently engaged students in collaborative learning where two or more students worked together to complete a project (Gill et al., 2015). As a result, Barbour and Kinsella's (2003) article was especially insightful despite being uncited and published 17 years ago. In the article they described a Canadian online teacher who was able to form a collaborative relationship with another AP European History teacher in the U.S. Throughout the year the two classes engaged in regular communication and collaborative projects that the two online teachers took turns evaluating. Barbour and Kinsella (2003) explained, "in essence, these two classes from two sides of the border became one class, completing the same assignments, taking the same tests, being instructed by the same teacher" (p. 31). While this case was not typical, it showed the potential of learner-learner interactions in online and blended courses. Other articles also touched on under-researched topics such as instructional design (Cavanaugh, 2008; Haughey \& Muirhead, 1999; McWalters \& Thompson, 1997; Mayse, 2015), parental support (Barbour, 2002; Cavanaugh, 2008; Haughey \& Muirhead, 1999; Mayse, 2015), on-site facilitators (Cavanaugh, 2008; McWalters \& Thompson, 1997), students with disabilities (Greer, Smith, \& Basham, 2014), homeschooling (Haughey \& Muirhead, 1999), and the need for and obstacles to online teacher professional development (Haughey \& Muirhead, 1999; McWalters \& Thompson, 1997).

The four data-based articles relied on surveys (Barbour, 2002; Greer, et al., 2014), interviews (Haughey \& Muirhead, 2009), observations (Mayse, 2015), and login data (Barbour, 2002). Two were in the top three most recently published articles in our data. As a result, the timeliness of their research may make them particularly valuable. For example, Greer et al. (2014) focused on practitioners' perceptions of online learners with disabilities and their perceived abilities to meet those students' needs at a distance. This research could be particularly helpful because research examining online students with disabilities is especially limited and much of the existing research has been published in outlets other than peer-reviewed journals (Rice \& Dykman, 2018). 
Mayse's (2015) uncited research examined students' use of resources in an online science course. This research was interesting because of its mixed methods that included student observations. The findings could also provide important insights to instructional designers who wish to improve students' use of online resources. However, the article's primary limitation was its reliance on the debunked theory of learning styles (see Kirschner \& van Merrienboer, 2013). While more research in the field needs to use and develop theoretical perspectives and frameworks (Lokey-Vega, Jorrin-Abellan, \& Pourreau, 2018), relying on unsound theories can be unproductive.

\section{Analysis of Low-cited Articles}

There were several patterns that emerged within the low-cited literature. The most consistent and overwhelming pattern was that the vast majority reported a specific case focused on a single program or context. In many of these cases various aspects of virtual schools in a specific jurisdiction were described (e.g., Florida in Burgess-Watkins, 2011; Georgia in Goss, 2011; Ohio in Wang \& Decker, 2014; Pennsylvania in Mann \& Barkauskas, 2014; Newfoundland and Labrador, Canada in Furey \& Murphy, 2005; Northwest Territories, Canada in McAuley, 1998; Australia in Stevens, 2009; New Zealand in Stevens, 2000; and Turkey in Sakar, 2011). These articles examined such diverse issues as demographics, multiculturalism, and social justice. Interestingly, an additional three articles discussed foreign language classes (Jeurissen, 2015; Lim \& Kim, 2008; Lin \& Zheng, 2015). For example, Jeurissen (2015) examined a virtual course on Te Reo Maori. Finally, these case studies also presented research ranging from the need for online librarians (Beck, 2015) to online personal fitness courses (Kane, 2004); from credit recovery courses (Pettyjohn \& LaFrance, 2014) to Advanced Placement courses (Barbour, 2001); and from parents' involvement in helping their children succeed in online courses (Curtis \& Werth, 2015) to the experiences of dyslexic students in an online class (Coy \& Hirschmann, 2014). These studies, although they have been low-cited to date, illustrate the rich history and diversity of K-12 online learning research.

Even within this group of case studies, additional patterns emerged. For example, there were 19 cases focused on international (i.e., non-American) settings, published in international journals, or written by international scholars. These 19 articles were written by 22 authors, 20 of whom were non-Americans. The international settings of their research are outlined above and included the countries of Australia, Canada, Korea, New Zealand, and Turkey. The international focus was also reflected in the journals in which these articles were published. Ten of the articles were published in journals outside of the U.S. (e.g., the Journal of Open Flexible and Distance Learning from New Zealand, the Canadian Journal of Career Development from Canada, the Welsh Journal of Education from Wales, the Australian Journal of Education from Australia, the Turkish Online Journal of Distance Education from Turkey, and Géocarrefour from France, just to highlight a few of these journals). Several scholars have found that the majority of research into K-12 online learning has been focused on the U.S. (Arnesen et al., 2019; Barbour, 2011, 2018), which may explain why many of these articles have been overlooked and thus remain low-cited. Interestingly, many of these journals are published in open access format and, for those journals that are not, many of these authors have provided copies of their articles through open scholarship networks (e.g., Academia.edu or ResearchGate).

As it was referenced above, another pattern within the case studies was a focus on rural education. There were 33 articles from Arnesen et al.'s (2019) data set that were published between the years of 1994 and 2001 (inclusive). Every low-cited article published during those years was 
focused on rural education. These articles examined the difficulties in K-12 distance education in those early years by exploring topics such as teachers' lack of preparation and pedagogical adaptations (Stevens, 1997), coordinating schedules among different entities (Benson, 1998), startup costs (Stevens 1997), and students' uncertainty about interacting with instructors and peers (Stevens, 2000). But, researchers also highlighted the advantages to rural students of distance education, such as more class choices (Barbour, 2001; Benson, 1998; Stevens, 2000), connections with other students who lived far away (McAuley, 1998), and the ability of high school students to stay in their communities to learn instead of being sent to urban centers (Stevens, 2000; 2001). While there were four other low-cited articles dealing with rural education that were published much later (Barbour \& Mulcahy, 2013; Barbour, Siko, \& Simuel-Everage, 2013; Kirby \& Sharpe, 2010; Stevens, 2009), these early articles highlight themes that have become foundational to K-12 distance and online learning: a focus on personalization, access, and flexibility in addressing the needs of all learners.

A second pattern that emerged from the low-cited literature was a focus on exploring the benefits, challenges, and/or potential of K-12 distance, online, and blended learning, often based solely on the authors' or stakeholders' perceptions. For example, there were several perceived benefits that were documented, such as individualization and flexibility (Furey \& Murphy, 2005; Kane 2004; Russell, 2006; Stevens, 1997) and the ability of online courses to serve diverse populations (Furey \& Murphy, 2005; Kane, 2004). These authors saw the flexibility and increased academic offerings of online courses as potentially helping populations as diverse as athletes and homeschoolers and students who had health issues or who needed accelerated learning opportunities or credit recovery. In contrast, there were six articles over a period of eight years listing perceived challenges of virtual learning, which have remained fairly constant. These challenges included providing for the initial costs, access issues, teacher hesitancy, and lack of teacher preparation (Benson, 1998; Furey, \& Murphy, 2005; Russell, 2003; Stevens, 1997). Benson (1998), for example, discussed helping teachers feel more comfortable in their new role as online teachers by giving them access to the technology they would be using and allowing them to experiment with it. Other perceived challenges included student attitudes and lack of the selfregulation and self-efficacy abilities needed to succeed in online settings (Russell, 2003, 2006).

Additionally, these articles spoke optimistically about the potential of online learning. These authors saw the benefits as growing over time and the challenges as distractions that could be overcome. In one example, Cavanaugh, Sessums, and Drexler (2015) discussed the potential for significant research as changes in pedagogy and context invite teachers - and even students into the research process. Similarly, Russell (2006) portrayed the increased potential for parents, educators, administrators, designers, technology personnel, and the students themselves to be involved in and responsible for students' education. As the title of Benson (1998) suggested, online learning opened educational "opportunities by closing the distance," increasing the potential for more individuals to benefit from the advantages offered in online and blended contexts.

Finally, many of these low-cited articles could also be organized around additional topical themes. For example, as might be expected, there were a number of articles that focused on comparing student performance based on delivery modality in some fashion or another (Curtis \& Werth, 2015; Lowes, Lin, \& Kinghorn, 2015; Lueken, Ritter, \& Beck, 2015). There were nine articles that focused on issues related to teaching in the online environment. To highlight just two examples, Stevens (2009) explored opportunities for urban, preservice teachers to interact with rural students, while Murphy and Rodríguez-Manzanares (2008) examined teachers' beliefs about 
learner-centered e-learning. Similarly, there were five articles that focused on issues related to online course design. Ryan and Beaulieu (2009) reviewed articles in an attempt to delineate elements of good online courses, while Smith and Harvey (2014) examined Khan Academy videos through the lens of the universal design for learning to explore K-12 online lesson alignment. Another topic that has seen significant coverage in the literature is policy issues related to K-12 online learning, which is also represented with eight low-cited articles. For example, Russell $(2003,2006)$ explored a variety of general policy issues that were raised by K-12 online learning environments, while others have explored policy issues in a specific jurisdiction (Barbour, 2005; Barbour \& Mulcahy, 2013; Stevens, 1995). Interestingly, a topic that has primarily received interest since the creation of the Center on Online Learning and Students with Disabilities (see http://www.centerononlinelearning.res.ku.edu/) is the topic of $\mathrm{K}-12$ online learning and populations with special needs. Yet the low-cited articles in our data set included five articles that fell under this broad topic and were published prior to the creation of the center. For example, Greer, Crutchfield, and Woods (2013) summarized the cognitive theory of multimedia learning and how it related to students with learning disabilities, while Tysinger, Tysinger, Diamanduros, and Kennedy (2013) focused on issues related to school psychologists who work in online schools. In terms of a topical analysis, the only article that did not fall into a specific topic with other articles was Barbour (2007), which discussed the major researchers in the field of K-12 online learning at the time and made the case for more scholars in the discipline of instructional technology.

\section{Conclusions and Implications}

In this study we analyzed 62 uncited and low-cited articles from the data collected by Arnesen et al. (2019). We wondered if these articles were simply irrelevant to current interests in K-12 online learning or if other factors influenced their low citation numbers. We found the articles to be both interesting and relevant, but they shared several attributes that may have contributed to the low citation counts. First, many of the articles were still relatively newly published, with almost half (43.5\%) of the articles being published in 2014-15. It is possible that these articles will be cited more frequently during the coming years.

Second, about half the articles were written in less well-known journals or journals that were difficult to access. In addition, the 62 articles of this study were scattered across 45 journals, with 39 of the journals each publishing only a single article from the original data set. The lack of journals dedicated to K-12 online learning may lead to valuable articles being missed (i.e., the single exception being Journal of Online Learning Research, which began publishing in 2015). Researchers may want to carefully consider their publication outlets if their goal is to have a greater impact on future research.

Third, many authors of these uncited and low-cited articles were well known in the field. For example, Barbour, who published 52 articles in the Arnesen et al. (2019) study, and Stevens, who published 18, may have published articles in smaller, more specific journals in order to reach more specific audiences. Stevens, for example, published an article entitled "Perceptions of educational opportunities in small schools in rural Australia and Canada" in Rural Society Journal, a narrow subject in a lesser-known journal. Similarly, Barbour published an article entitled "Enrichment opportunities for gifted students in rural areas: Online AP social studies sources," a program situated partly in Ohio and published in Ohio Council for the Social Studies Review. Barbour's and Stevens's articles also illustrate an important point. These uncited and low-cited 
articles may not actually be irrelevant but may be valuable and helpful to broader audiences and contexts.

Fourth, the topics of many of these articles had a narrow focus, investigating specific programs or jurisdictions, giving them seemingly limited application to other contexts. For example, just under half (i.e., $40 \%$ ) were written about contexts outside of the U.S. Because so much of K-12 online research is focused on the U.S., articles about other settings could attract less attention. Finally, many of the topics were focused on specific aspects of online learning, such as online librarians, home schoolers, Te Reo Maori language instruction, and dyslexic students, to name just a few. Researchers may have excluded these articles when researching broader topics. However, the articles' methods and findings should not be ignored and have the potential to make meaningful contributions to the field.

Finally, this study suggests several avenues for further research. Researchers could analyze the difference between specific authors' high, low, and uncited articles as well as the differences between low- and high-cited articles on the same subject. Further research could also address the readership of low and uncited articles. Are these articles useful to audiences that are looking for practical solutions? An understanding of the role of these articles and the contributions they can make can further benefit a growing and compelling field of scholarship. 


\section{References}

Arnesen, K. T., Hveem, J., Short, C. R., West, R., \& Barbour, M. K. (2019). K-12 online learning journal articles: Trends from two decades of scholarship. Distance Education, 40(1), 32-53. https://doi.org/10.1080/01587919.2018.1553566

Barbour, M. K. (2001). Enrichment opportunities for gifted students in rural areas: Online AP social studies sources. Ohio Council for the Social Studies Review, 37(1), 18-26.

Barbour, M. K. (2002). Bridging the home and school: A case study of one web-enabled technology. International Electronic Journal for Leadership in Learning, 6(11). https://journals.library.ualberta.ca/iejll/index.php/iejll/article/view/441

Barbour, M. K. (2005). From telematics to web-based: The progression of distance education in Newfoundland and Labrador. British Journal of Educational Technology, 36(6), 1055-1058. https://doi.org/10.1111/j.1467-8535.2005.00574.x

Barbour, M. K. (2007). Who's researching virtual schools: A case for instructional technologists. Distance Learning 4(1), 7-12.

Barbour, M. K. (2011). The promise and the reality: Exploring virtual schooling in rural jurisdictions. Education in Rural Australia, 21(1), 1-20.

Barbour, M. K. (2018). A history of K-12 distance, online, and blended learning worldwide. In K. Kennedy and R. Ferdig (Eds.), Handbook of research on K-12 online and blended learning (2nd ed., pp. 21-40). ETC Press. https://figshare.com/articles/Handbook_of_Research_on_K12 Online and Blended_Learning Second_Edition /6686813

Barbour, M. K., \& Kinsella, J. (2003). From Newfoundland to Illinois: The development of an AP European history course for the Illinois virtual high school. Journal of the Illinois Council for the Social Studies, 63, 25-35.

Barbour, M. K., \& Mulcahy, D. M. (2013). Examining enrollment trends in schools participating in online learning in Newfoundland and Labrador. The Morning Watch 41(1-2), 66-76.

Barbour, M. K., \& Reeves, T. C. (2009). The reality of virtual schools: A review of the literature. Computers and Education, 52(2), 402-416.

Barbour, M. K., Siko, J., \& Simuel-Everage, K. (2013). Pictures from an exhibition... of online learning: A creative representation of qualitative data. The Qualitative Report, 18(45), 1-15.

Beck, D. (2015). The online school librarian: Roles and responsibilities. TechTrends, 59(3), 77-84. https://doi.org/10.1007/s11528-015-0856-8

Benson, G. (1998). Opening opportunities by closing the distance. High School Magazine, 6(1), 4243.

Bozkurt, A., Akgun-Ozbek, E., Yilmazel, S., Erdogdu, E., Ucar, H., Guler, E., Sezgin, S., Karadeniz, A., Sen-Ersoy, N., Goksel-Canbek, N., Dincer, G. D., Ari, S., \& Aydin, C. H. (2015). Trends in distance education research: A content analysis of journals 2009-2013. The International Review of Research in Open and Distributed Learning, 16(1). http://www.irrodl.org/index.php/irrodl/article/view/1953

Burgess-Watkins, K. (2011). Online learning opportunities for K-12 students in Florida's Nassau County. Distance Learning, 8(1), 1-7. 
Carr-Chellman, A. A. (2015). Back to cyber school. E-Learn Magazine. http://elearnmag.acm.org/opinion.cfm?aid=2800834

Cavanaugh, C. (2008). Lessons from K-12 distance education in the U.S.A., 1986-2008. Revista Mexicana de Bachillaerato a Distancia, 1(1). http://revistas.unam.mx/index.php/rmbd/article/download/47163/42441

Cavanaugh, C., Sessums, C., \& Drexler, W. (2015). A call to action for research in digital learning: Learning without limits of time, place, path, pace...or evidence. Journal of Online Learning Research, 1(1), 9-15. https://www.learntechlib.org/primary/p/149851/

Clark, T. (2018). Program evaluation in K-12 online and blended learning. In K. Kennedy \& R. Ferdig (Eds.), Handbook of research on K-12 online and blended learning (2nd ed., pp. 121132). ETC Press. https://figshare.com/articles/Handbook of Research_on_K12 Online and Blended Learning_Second_Edition/6686813

Coy, K., \& Hirschmann, K. R. (2014), Professional development for special education teachers in virtual schools. International Journal of Dyslexia, 40(1), 17-21.

Curtis, H., \& Werth, L. (2015). Fostering student success and engagement in a K-12 online school. Journal of Online Learning Research, 1(2), 163-190. https://www.learntechlib.org/primary/p/150962/

Davis, N. E. (2012). 21 st century learning environments in the limelight, including virtual schooling. Computers in New Zealand Schools, 24(1), 70-76. https://www.otago.ac.nz/cdelt/otago063962.pdf

Furey, D., \& Murphy, E. (2005). K-12 virtual schools and schooling. The Morning Watch, 32(3-4). http://www.mun.ca/educ/faculty/mwatch/win05/MurphyFurey.htm

Gill, B., Walsh, L., Wulsin, C. S., Matulewicz, H., Severn, V., Grau, E., ... Kerwin, T. (2015). Inside online charter schools. Walton Family Foundation and Mathematica Policy Research. http://www.mathematicampr.com/ /media/publications/pdfs/education/inside_online_charter_schools.pdf

Goss, M. W. (2011). Georgia Virtual School. Distance Learning, 8(3), 41-45.

Greer, D. L., Crutchfield, S., \& Woods, K. (2013). Cognitive theory of multimedia learning, instructional design principles, and students with learning disabilities in computer-based and online learning environments. Journal of Education, 193(2), 41-50. https://doi.org/10.1177/002205741319300205

Greer, D., Smith, S., \& Basham, J. (2014). Practitioners' perceptions of their knowledge, skills and competencies in online teaching of students with and without disabilities. Journal of the American Academy of Special Education Professionals, (Spring-Summer), 150-165.

Hamilton, D. P. (1990). Publishing by —and for? - the numbers. Science, 250(4986), 1331-1332. http://www.garfield.library.upenn.edu/papers/hamilton1.html

Haughey, M., \& Muirhead, B. (1999). Virtual educations: Implications for society. Open Education Research, 2/3, 13-18.

Hu, M., Arnesen, K., Barbour, M. K., \& Leary, H. (2019). A newcomer's lens: A look at K-12 online and blended learning in the Journal of Online Learning Research. Journal of Online Learning Research, 5(1), 123-144. https://www.learntechlib.org/primary/p/195231/ 
Jeurissen, M. (2015). Learning Te Reo Maori via online distance education: A case study. Journal of Open Flexible and Distance Learning, $19(1)$. http://www.jofdl.nz/index.php/JOFDL/article/view/229

Kane, J. J. (2004). My dog ate the disk: An analysis of student and teacher perspectives of an online personal fitness course. Florida Journal of Health, Physical Education, Recreation \& Dance, $42(2), 8-12$

Kirby, D., \& Sharpe, D. (2010). An examination of rural secondary students' post-secondary education decisions. Canadian Journal of Career Development, 9(1), 4-14. http://cjcdonline.ca/wp-content/uploads/2014/11/An-Examination-of-Rural-SecondaryStudents-post-secondary-education-decisions.pdf

Kirschner, P. A., \& van Merriënboer, J. J. G. (2013). Do learners really know best? Urban legends in education. Educational Psychologist, 48(3), 169-183. https://doi.org/10.1080/00461520.2013.804395

Li, Y., Wu, C., Yan, E., \& Li, K. (2018). Will open access increase journal CiteScores? An empirical investigation over multiple disciplines. PLoS ONE, 13(8), 1-21. https://doi.org/10.1371/journal.pone.0201885

Lim, B., \& Kim, S. (2008). Issues and possibilities of CHLS (Cyber Home Learning System): Implications on language education. Multimedia Assisted Language Learning, 11(1), 9-33. http://kmjournal.bada.cc/wp-content/uploads/2013/05/11-1-1Lim.pdf

Lin, C.-H., \& Zheng, B. (2015). Teaching practices and teacher perceptions in online world language courses. Journal of Online Learning Research, 1(3), 275-303. https://www.learntechlib.org/primary/p/171055/

Lokey-Vega, A., Jorrin-Abellan, I. M., \& Pourreau, L. (2018). Theoretical perspectives in K-12 online learning. In K. Kennedy and R. Ferdig (Eds.), Handbook of research on K-12 online and blended learning (2nd ed., pp. 65-90). ETC Press. https://figshare.com/articles/Handbook_of_Research_on_K12 Online and_Blended_Learning_Second_Edition_/6686813

Lowes, S. (2014). A brief look at the methodologies used in the research on online teaching and learning. In R. Ferdig \& K. Kennedy (Eds.), Handbook of research on K-12 online and blended learning (pp. 83-104). ETC Press. https://figshare.com/articles/Handbook of Research_on_K12 Online and Blended_Learning/6686810

Lowes, S., \& Lin, P. (2018). A brief look at the methodologies used in the research on online teaching and learning. In K. Kennedy \& R. Ferdig (Eds.), Handbook of research on K-12 online and blended learning (2nd ed., pp. 91-110). ETC Press. https://figshare.com/articles/Handbook_of_Research_on_K12 Online and_Blended_Learning_Second_Edition_/6686813

Lowes, S., Lin, P., \& Kinghorn, B. (2015) Exploring the link between online behaviours and course performance in asynchronous online high school courses. Journal of Learning Analytics, 2(2), 169-194. https://learning-analytics.info/journals/index.php/JLA/article/view/4264

Lueken, M., Ritter, G., \& Beck, D. (2015). Value-added in a virtual learning environment: An evaluation of a virtual charter school. Journal of Online Learning Research, 1(3), 305-335. https://www.learntechlib.org/primary/p/150993/ 
Mann, B., \& Barkauskas, N. (2014). Connecting learners or isolating individuals?: The .social justice frames in the cyber charter schools in Pennsylvania. International Journal of Cyber Ethics in Education, 3(2), 39-50.

Mayse, D. (2015). How 7th grade students are using resources for learning in an online science course. Journal of Online Learning Research, 1(3), 337-363. https://www.learntechlib.org/primary/p/149948/

McAuley, A. (1998). Virtual teaching on the tundra. TECHNOS, 7(3), 11-14.

McWatters, G., \& Thompson, L. (1997) The EDEN Project: Electronic Distributive Education Network distance education solutions for the mainstream. Journal of Distance Education, 12(1), 277-284. http://www.jofde.ca/index.php/jde/article/view/285/438

Molnar, A., Miron, G., Elgeberi, N., Barbour, M. K., Huerta, L., Shafer, S. R., Rice, J. K. (2019). Virtual Schools in the U.S. 2019. National Education Policy Center. http://nepc.colorado.edu/publication/virtual-schools-annual-2019

Murphy, E., \& Rodríguez-Manzanares, M. (2008). High school teachers' beliefs about learnercentred e-learning. E-Learning and Digital Media, 5(4), 384-395. https://doi.org/10.2304/elea.2008.5.4.384

Pettyjohn, T., \& LaFrance, J. (2014). Online credit recovery: Benefits and challenges. NCPEA Education Leadership Review of Doctoral Research, 1(1). https://files.eric.ed.gov/fulltext/EJ1105728.pdf

Piwowar, H., Priem, J., Larivière, V., Alperin, J. P., Matthias, L., Norlander, B., ... Haustein, S. (2018). The state of OA: A large-scale analysis of the prevalence and impact of open access articles. PeerJ, 6, e4375. https://doi.org/10.7717/peerj.4375

Rice, M. F. \& Dykman, B. (2018). The emerging research base on online learning and students with disabilities. In K. Kennedy and R. Ferdig (Eds.), Handbook of research on K-12 online and blended learning (2nd ed., pp. 189-206). ETC Press. https://figshare.com/articles/Handbook_of_Research_on_K12 Online and_Blended_Learning_Second_Edition_/6686813

Russell, G. (2003). The potential and problems of virtual schooling. Welsh Journal of Education, $12(1), 40-52$.

Russell, G. (2006). Globalization, responsibility and virtual schools. Australian Journal of Education, 50(2), 140-154. https://doi.org/10.1177/000494410605000204

Ryan, T. G., \& Beaulieu, R. (2009) Secondary online education: A review and synthesis of central elements. Turkish Online Journal of Distance Education, 20(1). http://tojde.anadolu.edu.tr/makale goster.php?id=464

Sakar, A.N., \& Ozturk, O. (2011). The "community services" course through distance education: Evaluation of primary school students. Turkish Online Journal of Distance Education, 12(1). http://tojde.anadolu.edu.tr/yonetim/icerik/makaleler/650-published.pdf

Smith, S. J., \& Harvey, E. E. (2014). K-12 online lesson alignment to the principles of universal design for learning: The Khan Academy. Open Learning, 29(3), 222-242. https://doi.org/10.1080/02680513.2014.992402 
Stevens, K. (1995). Some policy considerations in the changing relationship between area schools and New Zealand rural communities. Social Policy Journal Of New Zealand Te Puna Whakaaro, 5(1). http://www.msd.govt.nz/about-msd-and-our-work/publicationsresources/journals-and-magazines/social-policy-journal/spj05/05-school-relationship.html

Stevens, K. (1997). Three dimensions of leadership in a telelearning environment: School networking, collaborative teaching and open administration. The Morning Watch, 25(1-2). http://www.mun.ca/educ/faculty/mwatch/fall97/three.htm

Stevens, K. (2000) Telelearning and the education of rural students in Newfoundland and New Zealand. Géocarrefour, 75(1), 87-92. http://doi.org/10.3406/geoca.2000.2458

Stevens, K. (2001). A four-step process for the development of knowledge-building communities in a digital intranet. Journal of Distance Learning, 6(1), 45-48.

http://www.jofdl.nz/index.php/JOFDL/article/view/146

Stevens, K. (2009). Perceptions of educational opportunities in small schools in rural Australia and Canada. Rural Society Journal, 19(2), 118-126. https://doi.org/10.5172/rsj.19.2.118

Stevens, K., \& Dibbon, D. (2002). Educational innovation in small communities: The introduction of e-learning to extend student educational and career opportunities. The Innovation Journal, 8(4). http://www.innovation.cc/peer-reviewed/stevens-dibbon.pdf

Tainer, J. A., Abt, H. A., Hargens, L. L., Bott, D. M., Lancaster, F. W., Pannell, J. H., Nuhfer, E. B., McGehee, C. L., Banks, W. A., \& Pendlebury, D. A. (1991). Science, citation, and funding. Science, 251(5000), 1408-1411. https://doi.org/10.1126/science.251.5000.1410-b

Tysinger, P. D., Tysinger, J. A., Diamanduros, T. D., \& Kennedy, K. (2013). K-12 online learning and the training needs for school psychology practitioners. School Psychology Forum, 7(3), 76-88.

Van Noorden, R. (2017). The science that's never been cited: Nature investigates how many papers really end up without a single citation. Nature, 552, 162-164. https://www.nature.com/magazine-assets/d41586-017-08404-0/d41586-017-08404-0.pdf

Wang, Y., \& Decker, J. R. (2014). Examining digital inequities in Ohio's K-12 virtual schools: Implications for educational leaders and policymakers. International Journal of Educational Reform, 23(4), 294-314. https://doi.org/10.1177/105678791402300404

West, R.E. (2011). About this article and new series. Educational Technology, 51(4), 60.

West, R. E. (2016). Insights from the journal analysis series: What we have learned about educational technology research. Educational Technology, 56(1), 41-45.

Zawacki-Richter, O., Baecker, E. M., \& Vogt, S. (2009). Review of distance education research (2000 to 2008): Analysis of research areas, methods, and authorship patterns. The International Review of Research in Open and Distributed Learning, 10(6), 21-50. http://www.irrodl.org/index.php/irrodl/article/view/741 